\title{
Is free pre-primary education associated with increased primary school completion? A global study
}

\author{
Alison Earle 1* $^{*}$, Natalia Milovantseva ${ }^{2}$ and Jody Heymann ${ }^{1}$
}

*Correspondence:
aearle@ph.ucla.edu
1'WORLD Policy Analysis
Center, University
of California, Los Angeles, 621
Charles E. Young Dr. South,
Los Angeles, CA 90095, USA
Full list of author information
is available at the end of the
article

*Correspondence:

aearle@ph.ucla.ed

Center, University

of California, Los Angeles, 62

Charles E. Young Dr. South,

Full list of author information article

\begin{abstract}
While global enrollment in primary education has increased significantly particularly since it became a target of the United Nations "Education for All" initiative and one of the Millennium Development Goals, primary completion rates have remained virtually unchanged since 1999. Evidence from studies of individual programs in a range of countries suggests that enrollment in pre-primary education can improve school readiness and achievement in primary school, and therefore, potentially raise primary completion rates. As research has also found that provision of free education is associated with higher enrollment, we hypothesize that provision of free and compulsory pre-primary education will be associated with higher primary school completion rates. Further, we hypothesize that free pre-primary education will have the largest impact where completion rates have been lowest. Using a database of quantitative, globally comparable measures of national provision of free pre-primary education we created, and data from UNESCO's Institute for Education Statistics, we analyze the 104 nations with complete data. We conduct multivariate quantile regression analyses. We find that, controlling for national income and level of urbanization, provision of at least 1 year of free and compulsory pre-primary education is associated with a nearly 10 percentage point increase in primary school graduation rates for countries at the median and a 12 percentage point increase in rates for primarily low- and lower-middle-income countries at the lower end of the distribution.
\end{abstract}

\section{Introduction}

The world has made substantial progress in increasing primary education enrollment rates, particularly among girls, following a series of global commitments to increase access to primary education including the United Nations (UN) Convention on the Rights of the Child, Art. 28 (1989), UN Millennium Development Goal 2 (2000), and United Nations Educational, Scientific and Cultural Organisation (UNESCO) Education for All goals (UNESCO 1990, 2010). The greatest overall increase was among lowincome countries where primary school net enrollment rates increased from $54 \%$ in 2000 to an estimated $85 \%$ in 2015 , and the female-male ratio from 0.85 to 0.94 (UNESCO IS 2017a). In eleven countries in sub-Saharan Africa, primary enrollment rates rose at least 20 percentage points from 1999 to 2012 (UNESCO 2015). 
Evidence suggests that eliminating tuition fees has been one of the most important drivers of primary enrollment increases, particularly in low-income environments and where the rates of attending primary education are low (Kattan 2006). For example, a 2007 evaluation of 32 low-income countries that instituted school user fees as a component of the Structural Adjustment Programs of the 1980s revealed that countries experienced increases in enrollment after eliminating these fees, and that countries with well-planned strategies of removing fees experienced little or no adverse effect on the quality of education (Nielsen 2009). Studies of individual countries find similar results. A year after Malawi introduced free primary education in 1994, enrollment rates increased 51\%; in Burundi, which eliminated tuition in 2006, net primary school enrollment rose from $41 \%$ in 2000 to $94 \%$ in 2010 (UNICEF and the World Bank 2009; UN Statistics Division 2013). Eliminating fees may also reduce socioeconomic gaps in education access, suggesting school fees are particularly significant barriers for lower income families. In Uganda, for example, after fee abolition in 1997, the difference in primary school attendance rates between the bottom and the top quintiles decreased from 43 percentage points (46\% versus $89 \%$ ) in 1992 to just 11 percentage points $(78 \%$ versus 89\%) in 1997 (Deininger 2003). The vast majority of countries have legislated tuition-free school at the primary level, and just 15 nations have yet to make primary education free and compulsory (Heymann 2013; de Guzman Chorny et al. 2014).

Despite notable gains in primary school enrollment (UNESCO IS 2017a), completion rates $^{1}$ have remained virtually unchanged since 1999 at between 76 and 77\%, with rates in sub-Saharan Africa and South and West Asia far below North America and Western Europe (56\%, 77\% and 94\%, respectively, in 2013) (UNESCO IS 2017b). The most recent report from the Education for All movement, a partnership of four UN agencies and the World Bank, identified inadequate completion as one of the main challenges to achieving universal primary education (UNESCO 2015). While there is some evidence showing that making primary school compulsory supports completion (Zhang and Minxia 2006; Brunello et al. 2009), the persistent gap between enrollment and completion rates and the stagnant, low completion rates in many low-income countries highlight the critical importance of identifying the other promising policies and approaches that support students' ability to finish primary school.

Two broad areas of the literature lend support to the notion that policies that improve the affordability of and attendance at pre-primary school ${ }^{2}$ may contribute to higher primary ${ }^{3}$ completion rates, especially among countries that have struggled with low completion rates. First, extensive research has documented the significant impact that early childhood experiences and education have on cognitive development and subsequent learning outcomes (Shonkoff and Phillips 2000; Heckman 2006; Knudsen et al. 2006; Grantham-McGregor et al. 2007). Second, numerous studies conducted in a wide range of countries using a range of methodologies have found that completion of pre-primary

\footnotetext{
${ }_{1}$ The completion rate is defined as the fraction of children that remain in school from the first to last grade of primary education (UNESCO IS 2017b)

2 Unless otherwise noted, "pre-primary education" refers to education "designed for ... children from age 3 years to the start of primary education," or International Standard Classification of Education (ISCED) Level 0 education (UNESCO 2012, p. 26).

${ }^{3}$ Unless otherwise noted, "primary education" refers to education for which the "... customary or legal age of entry is usually not below 5 years old nor above 7 years old. This level typically lasts 6 years, although its duration can range between 4 and 7 years. Primary education typically lasts until age 10-12," or ISCED Level 1 education (UNESCO 2012, p. 30).
} 
education is associated with school readiness, improved primary school achievement and completion rates (For a review, see Rao et al. 2014; Engle et al. 2011; Camilli et al. 2010; Duncan et al. 2007). For example, a meta-analysis of 123 studies of the effects of early childhood education programs conducted over the past five decades found a statistically significant, positive average effect on timely progress through primary school, socio-emotional outcomes, and for cognitive outcomes measured variously by IQ tests and achievement tests in math, reading, writing, spelling, and verbal skill development (Camilli et al. 2010). Numerous individual country studies from both high- and middleincome countries have reported consistent findings. A few of the many possible examples follow. A United States (US) study by Magnuson et al. (2007) found that students who complete 1 year of pre-kindergarten enter primary school with higher math and reading skills that children who are at home or in other care. A large, cross-sectional study in Chile found that having attended at least 1 year of pre-school was associated with higher math, reading, and social science test scores in the fourth grade (Cortázar 2015). Similarly, an analysis of national survey data from Brazil showed a strong association between completion of preschool and lower rates of primary school grade repetition (World Bank 2001).

Studies done in developing nations mirror those from middle- and high-income countries. For example, a study examining a national sample of 6-year-olds in Zambia found that participation in an early childhood education program was significantly and positively associated with seven domains of children's school readiness (McCoy et al. 2017). A study of 180 students from each of 30 pre-primary schools in Bangladesh found that those who had the opportunity to attend scored higher on achievement tests in five competencies (speaking, writing, reading, oral mathematics and written mathematics) in first grade and second grade (Aboud and Hossain 2011). Jaramillo and Tietjen (2001) examined over 800 children across a range of preschool programs in two African countries, one very poor, Guinea and one comparatively wealthy, Cape Verde, and in both countries students who attended preschool had significantly higher overall cognitive development scores than the control group. Gains were greater for students that attended for 2 years (compared to one), for girls, and in Guinea, for students of middle- and low-socioeconomic status. Studies using longitudinal analyses reaffirm the findings from cross-sectional studies (Berlinski et al. 2008, 2009). Results vary across studies when it comes to which affects endure, for how long, and under what circumstances.

Studies using an experimental or quasi-experimental design provide the strongest evidence of a causal relationship. Studies using these rigorous designs from the US (Deming 2009) and other OECD countries as well as non-OECD countries have shown that attendance in pre-primary education has a significant impact on success in primary school, and, importantly, especially benefits children from low-income households (see Havnes and Mogstad (2011) for Norway; Dumas and Lefranc (2010) for France; Martinez et al. (2012) for Mozambique; Berlinski et al. (2009) for Argentina; Berlinski et al. (2008) for Uruguay; Campbell et al. (2001), Barnett and Masse (2007), and Besharov et al. (2011) for the US).

Although the studies described above demonstrate a positive relationship between attendance in pre-primary education and primary school outcomes, these studies have not examined what may work at a national level to increase pre-primary attendance 
and whether these interventions then advance children's primary school outcomes on a national scale. The previous studies have primarily focused on intervention trials that are not at scale (e.g., at a community or local level not national), or on examining programs at a national scale whose participants have voluntarily enrolled (and who may be different in other respects from children who do not). In this study, we extend the literature on determinants of primary education completion by examining national-level public policies establishing free and/or compulsory pre-primary education for all ageappropriate children. This study focuses on one specific question faced by policymakers globally in widely varying contexts for early childhood education. Utilizing a new, global data source we developed based on the latest available data on free and compulsory preprimary education in nations around the world, we examine whether the provision of at least 1 year of free and/or compulsory pre-primary education advances primary school completion.

Using these public policies as instruments we can address two gaps in knowledgewill pre-primary have an impact when provided on a national scale for families where they do not self-select in, and is it sufficient for it to be free or is it important for it to be compulsory as well, similar to primary education. Lastly, using quantile regression analysis we are able to examine whether, as suggested by the evidence, the effect of free and compulsory education will be larger in countries where the need for improvements in primary school completion rates is greatest.

\section{Methods}

We examine the effect of two public policies which reflect the choices of policymakers providing free and compulsory pre-primary education. Enrollment in pre-primary education, on the other hand, is a function of observed and unobserved child and family characteristics which may be correlated with the likelihood of primary graduation. As a result, using enrollment as a predictor in the regression model would generate biased estimates. To correct for the potential endogeneity, we use an indicator of a national policy of pre-primary education as an instrument for pre-primary participation. The policy indicator is a valid instrument first because it is correlated with pre-primary enrollment (enrollment rates should be higher in countries with free and compulsory education). Second, the provision of free and compulsory pre-primary education is determined by national policymakers not parents (directly at least) so therefore, it is independent of the family and individual-level characteristics that are correlated with both pre-primary enrollment and primary graduation, and as such the policy is uncorrelated with the error term in a standard regression model, the second criteria for a valid instrument.

To assess the effect of national pre-primary policies on graduation rates from primary school, we examine the pre-primary education policy (compulsory and/or free) in place during the year just before the children whose graduation rates are used as the outcome variable would be entering primary school, or the year when these children would have been entering the final year of pre-primary education if it were available. In this study, we use the most recent data on primary graduation rates available between 2009 and 2014 and data on policies regarding the provision of free and/or compulsory pre-primary education (or lack thereof) in the year when students eligible to graduate would have been entering their last year of pre-primary school if it was provided (2002-2009). 


\section{Data}

\section{Data sources}

To identify which countries have made pre-primary education tuition-free, we created a new global database that captures policies on the provision of pre-primary education at a national level. The quantitatively comparable data were created from reviewing and coding national government reports to UNESCO International Bureau of Education from the 7th (2006/2007) and the 8th edition (2010/2011), and the 48th International Conference on Education country reports (2008). These reports were used as our main sources because they provide comparable qualitative data on the largest number of nations. The reports contained a comprehensive discussion of national educational systems, including a description of educational principles, educational laws and basic regulations, administration and management, structure and organization, and educational process.

When data were incomplete or unavailable through these sources, we supplemented them with country profiles and reports available through the following sources: World Bank's Systems Approach for Better Education Results (SABER); UNESCO's Planipolis, a portal of education plans from UN member states; UNESCO's Early Childhood Education and Care country reports for the Education for All Global Monitoring Report, UNESCO's Global Database on the Right to education database, and Eurypedia, a database of European Union (EU) country education policies. These sources were reviewed through June 2017 for policies in place during the relevant year per the calculation described above. The information in the reports and documents was systematically coded into a set of quantitative variables. To assure comparability, a coding framework was established to capture provision details and allow meaningful comparisons across programs instituted by different nations. At least two researchers separately reviewed sources for each country and compared coding decisions to confirm standard interpretation and to reduce the potential for human error or inconsistency. This followed the rigorous methodology for creating quantitative indicators from detailed educational policy and legal texts used in previous studies (Heymann 2013; Quamruzzaman et al. 2014; Heymann et al. 2014).

To increase comparability of policies across countries, we took into account that nations refer to pre-primary education using different terms, including early childhood education, nursery school, pre-primary program, preschool, kindergarten, or preparatory school. We used UNESCO's International Standard Classification of Education (ISCED) definition of pre-primary education, the older age category within Level 0 education, which follows. "ISCED level 0 programmes target children below the age of entry into ISCED level 1 . There are two categories of ISCED level 0 programmes: early childhood educational development and pre-primary education. The former has educational content designed for younger children (in the age range of 0 to 2 years), whilst the latter is designed for children from age 3 years to the start of primary education" (UNESCO 2012). If the entrance age to primary school is five, we examined the educational programs provided for children aged three and four. If the first year of primary education is termed a "reception year" or similarly, we considered it a part of primary education and it was not captured as a pre-primary program in the dataset. When reports contain 
Table 1 Description of analytic sample compared with sample of all UN member states: income level and geographic region

Countries in the in primary graduation rate All UN member

regression $(n=104) \quad$ countries

$(n=193)$

\begin{tabular}{lcr}
\hline Level of income (\%) & & 18 \\
Low & 13 & 29 \\
Lower-middle & 33 & 27 \\
Upper-middle & 35 & 26 \\
High & 20 & 18 \\
Geographic region (\%) & & 16 \\
Americas & 26 & 28 \\
East Asia and Pacific & 13 & 10 \\
Europe and Central Asia & 21 & 4 \\
Middle East and North Africa & 12 & 25 \\
South Asia & 4 & 24
\end{tabular}

All percentages are rounded to the nearest whole number. Some percentages may not always sum exactly to $100 \%$ as a

result of rounding. National income and regional groupings used are based on 2011 World Bank classifications

pre-primary education policy information on subnational level, our data reflect provisions that apply to the majority of territorial units in the country.

The data on national primary education graduation rates were obtained from the UNESCO Institute of Statistics Data Centre ("gross graduation ratio from primary education, both sexes (\%)", 2009 through 2014) (UNESCO 2017c).

The data on countries' per capita income, proxied by per capita gross domestic product (GDP), categorized level of income, level of urbanization, and geographic region were drawn from the World Bank's World Development Indicators Data (World Bank 2017).

\section{Sample characteristics}

In our analysis, we use the sample of 104 countries for which data on both primary education graduation rates and pre-primary education provision were available. Table 1 describes the sample of countries in our analysis and compares it to all 193 countries in the world that are UN members. The first column shows the percentage of countries in each income category (using World Bank categories) and the percentage of countries in our sample that are in each of the five regions (using World Bank regional classification). The second column displays the regions and income level of the global sample of 193 countries.

Overall, the two samples are similar in terms of income level and geography. The sample with data on primary school graduation rates has a larger percentage of middle-income countries. Geographically, this sample has a higher percentage of nations from the Americas (26\% vs. $18 \%$ ) but smaller percentage from Europe and Central Asia (21\% vs. $28 \%)$.

128 countries had primary graduation rate data between 2009 and 2014. 104 of these also had corresponding data on pre-primary provision in the year of pre-primary entry. 
Of these, 17 countries provided free and compulsory pre-primary education, 16 provided free but not compulsory pre-primary education while the remaining 71 did not provide free pre-primary education.

For the 104 countries in our analytic sample with both pre-primary provision and primary graduation data, the average gross primary graduation rate is $83.8 \%$.

\section{Description of variables}

Outcome variable

Primary gross graduation rate is defined as the number of children who are reported to have graduated from primary school (regardless of age) expressed as a percentage of the population at the theoretical graduation age for primary school. Data on net primary school graduation rates which exclude enrollment of under- and over-aged children were not available from the UNESCO Institute of Statistics at the time of our study. As described above, we used the most recent year of primary graduation rate data available between 2009 and 2014.

\section{Independent variables}

As noted above, we identified and used pre-primary education policy data for the year when students eligible to graduate from primary school would have entered one final year of pre-primary education based on the duration of primary education. As an example, if 2014 primary graduation data were available and primary school level of education was 5 years in length, then the calculation for the relevant year of pre-primary policy data would be: $2014-2005=2009$ then subtract 1 more year $=2008$. In our sample, the resulting policy data ranged from 2002 to 2009 . We refer to this below in this section as the "pre-primary year".

Countries classified as having free pre-primary education ${ }^{4}$ were those where law or policy provided at least 1 year of pre-primary education in the pre-primary year, using the UNESCO definition of pre-primary (older category of Level 0 education), and charged no tuition or educational fee (although other fees could be charged for such things as meals or field trips).

Countries with compulsory pre-primary education were those where law or policy mandated attendance for at least 1 year of pre-primary education using the UNESCO definition of pre-primary (older category of Level 0 education).

Countries providing free and compulsory pre-primary education were those countries where there was a policy in place in the pre-primary year providing at least 1 year of both free and compulsory pre-primary education. This variable was coded as missing if there were missing data for either the indicator of "free" or "compulsory."

\section{Control variables}

Existing large sample studies on national-level policies and primary completion rates find consistently that a country's level of national economic development and level of urbanization both strongly influence educational attainment and graduation rates, and are thus included as control variables. In the studies for which the percentage of the

\footnotetext{
${ }^{4}$ From here on, we use the term, "free pre-primary education" to refer to "tuition-free pre-primary education.
} 
population that is between 0 and 14 years of age is included, the coefficient is at times significant (Michaelowa and Weber 2007; d'Aiglepierre and Wagner 2013), however, it is highly correlated with per capita GDP $(r=0.83-0.84)$, so is not included in addition to per capita GDP. Findings regarding governance measures (effectiveness, political stability, accountability and voice.) have been inconsistent (Michaelowa and Weber 2007; Richards and Vining 2015; Dreher et al. 2008). An area where evidence is more mixed is the financing of education including domestic expenditures and foreign aid for education (Michaelowa and Weber 2007; Yogo 2017; d'Aiglepierre and Wagner 2013; Ruff 2016; Bruns et al. 2003; Dreher et al. 2008). In the studies where these measures are found to be significant, the effects are small which may be explained by the mediating role of governance; the impact is likely to be shaped by a nation's ability to spend dollars well and effectively. Finally, also significant is adult or female literacy rate (Richards and Vining 2015). Its relevance to rates of primary completion is unsurprising given that household level studies consistently find that parental level of education, particularly maternal education and literacy is a strong predictor of children's attainment (Holmlund et al. 2011). While this may be associated with voluntary attendance at preschool, there is no evidence that it is a confounder for examining the impact of policies on compulsory preschool.

National income is proxied by per capita GDP. The per capita GDP is measured in current US dollars (where the current year varies depending on the year for which graduation rate data are available and the corresponding number of years of primary and pre-primary education). To account for the difference in the impact of income at the lower and the higher ends of the national income spectrum, the natural logarithm of per capita GDP was utilized. Average per capita GDP over the entire pre-primary and primary educational period was used in analyses to ensure that one unusual economic year did not introduce any bias in the estimates.

Urbanization is defined as the percentage of population living in an urban area. Rates of urban population refer to the number of people living in an urban area as defined by national statistical offices expressed as a percentage of the total population estimates. The average urbanization rate over the entire pre-primary and primary education period was used in analyses.

\section{Analytic approach}

A multivariate quantile regression analysis was conducted to investigate whether the provision of at least 1 year of free pre-primary education was associated with an increase in primary school graduation rates, and whether the magnitude and significance of the association were greater in the countries with low primary school completion rates. A quantile regression analysis estimates coefficients for each of the specified quantiles or percentiles of the distribution of the dependent variable, in this case, the primary completion rate. Using this type of regression, we can examine whether the effect of free and compulsory education is larger in countries where the need to improve primary school completion rates is greatest. We estimate the effect when primary completion rates are low, at the 25th percentile, but also at the median (50th percentile). In addition, quantile regression analysis places no restrictions on 
the assumption regarding the error distribution so is appropriate for modeling data with unequal variation as is the case with the primary completion rate data used in this study (Koenker and Hallock 2001).

The effect of provision of at least 1 year of pre-primary education can be estimated at any percentile of the distribution of the dependent variable, e.g., 5 th $(0.05$ percentile), 10th ( 0.10 percentile), etc. We estimate 50th and 25th quantile regressions using a bootstrap technique as it has been shown to provide robust results and is generally preferred as more practical than asymptotic techniques (Hao and Naiman 2007). The estimated coefficient for a given quantile is interpreted as the difference in the gross graduation rate for a one unit change in the explanatory variable at the relevant percentile of the distribution of gross graduation rates. For example, the estimated coefficient for the 25th quantile is the difference in the gross graduation rate for a one-unit change in the explanatory variable, for example, provision of at least 1 year of tuitionfree pre-primary education as compared to no tuition-free pre-primary-at the 25th percentile of the conditional distribution of graduation rates. Because the dependent variable, the gross graduation rate, is a percentage, the estimated coefficient is interpreted as a percentage-point change.

We fit a model in which our dependent variable was the primary school graduation rate for the most recent available year from 2009 to 2014, and our key predictor variable was an indicator of whether a policy of free pre-primary education was in place in the year when the cohort for which we had graduation rate data would have entered a final (or only) year of pre-primary school. Average per capita GDP and urbanization over the entire pre-primary and primary educational period were used as control variables.

We first examine the distribution of pre-primary policy configurations in the year before potential primary school graduates would have entered pre-primary school. We then estimate two models, one assessing the individual effect of provision of free pre-primary education, and a second assessing the effect of free and compulsory preprimary education. We examine the differential effects for low-graduation-rate countries, at the 25th percentile of the distribution, and average-graduation rate countries, at the 50 th percentile.

\section{Results}

How often is free and/or compulsory pre-primary education available just prior to when children should enter primary school?

In $16 \%$ of countries in our sample, free and compulsory pre-primary education was available in the year prior to entry to primary school. Nearly the same number of countries, $15 \%$ of the sample, provided free but not compulsory pre-primary education in the year prior to entry to primary school. The remaining $69 \%$ provided no preprimary education.

\section{Is provision of free pre-primary education associated with higher primary graduation} rates?

Provision of free pre-primary education alone in the year prior to entry to primary school was not found to significantly improve completion rates. Provision of free 
Table 2 Quantile regression models of the relationship between free and compulsory preprimary education and primary school gross graduation rates

\begin{tabular}{|c|c|c|c|c|}
\hline & $\begin{array}{l}0.50 \text { quantile } \\
\beta \\
\text { (SE) }\end{array}$ & $\begin{array}{l}0.25 \text { quantile } \\
\beta \\
\text { (SE) }\end{array}$ & $\begin{array}{l}0.50 \text { quantile } \\
\beta \\
\text { (SE) }\end{array}$ & $\begin{array}{l}0.25 \text { quantile } \\
\beta \\
\text { (SE) }\end{array}$ \\
\hline Tuition-free pre-primary & $\begin{array}{l}5.76 \\
(3.88)\end{array}$ & $\begin{array}{l}6.80 \\
(6.82)\end{array}$ & & \\
\hline Tuition-free and compulsory & & & $\begin{array}{l}9.61^{*} \\
(4.26)\end{array}$ & $\begin{array}{l}12.22^{*} \\
(6.08)\end{array}$ \\
\hline Tuition-free but not compulsory & & & $\begin{array}{l}4.37 \\
(5.86)\end{array}$ & $\begin{array}{l}4.87 \\
(8.14)\end{array}$ \\
\hline Natural log of per-capita GDP & $\begin{array}{l}9.41^{* * *} \\
(2.79)\end{array}$ & $\begin{array}{l}9.72^{* *} \\
(3.11)\end{array}$ & $\begin{array}{l}9.36^{* *} \\
(3.02)\end{array}$ & $\begin{array}{l}12.59^{* * *} \\
(2.84)\end{array}$ \\
\hline Percent of population living in urban area & $\begin{array}{l}-0.04 \\
(0.11)\end{array}$ & $\begin{array}{l}0.12 \\
(0.19)\end{array}$ & $\begin{array}{l}-0.08 \\
(0.11)\end{array}$ & $\begin{array}{l}-0.02 \\
(0.16)\end{array}$ \\
\hline Constant & $\begin{array}{l}-11.98 \\
(27.11)\end{array}$ & $\begin{array}{l}-37.20 \\
(24.24)\end{array}$ & $\begin{array}{l}-10.94 \\
(29.13)\end{array}$ & $\begin{array}{l}-58.50^{*} \\
(22.53)\end{array}$ \\
\hline Observations & 104 & 104 & 104 & 104 \\
\hline Pseudo $R^{2}$ & 0.21 & 0.37 & 0.21 & 0.39 \\
\hline
\end{tabular}

Standard errors are reported in parentheses

${ }^{*},{ }^{* *},{ }^{* *} p \leq 0.05, p \leq 0.01$, and $p \leq 0.001$, respectively

pre-primary education in the year prior to entry to primary school was not significant at either the 25th or 50th percentile of the primary graduation rate distribution (see Table 2).

Is provision of free and compulsory pre-primary education associated with higher primary completion rates?

We next estimated the effects for free and compulsory, and free but not compulsory, separately compared to the base case of neither free nor compulsory in the year prior to primary school. Again, the quantile regression analysis produces estimates for the 25th and 50th or median part of the distribution of primary graduation rates. In both models, provision of free but not compulsory education was not significant (the effect size was estimated at between 4.4 and 4.8 percentage points but with large standard errors). The effect of free and compulsory provision in the year prior to primary school was significant in both the median and 25th quantile models, but the effect was larger for the 25th quantile. In the median model, provision of free and compulsory education in the year prior to primary school was associated with 9.6 percentage point higher primary education gross graduation rates $(p<0.05)$ compared to no pre-primary education provision, while in the 25th quantile model, the effect was 12.2 percentage points $(p<0.05)$. These results are summarized in Table 2 .

\section{Discussion}

While the world has come a long way toward achieving universal primary education, progress is uneven. Rates of primary school completion in the poorest countries lag behind the rest of the world, and the gap between wealthy and economically disadvantaged children in many countries is increasing (UNESCO 2015). This study uses a unique 
global policy database to examine the potential of one policy approach to achieving higher rates of primary completion: increasing primary school readiness and achievement by increasing enrollment in pre-primary school through free and compulsory provision. Understanding the degree to which provision of a year of free and/or compulsory pre-primary education is associated with higher rates of primary school completion can inform efforts to increase universal attainment of primary education across all nations. We find that while there was no association with provision of at least 1 year of free preprimary education, we found a significant positive effect when policies require that a final (or only) year of pre-primary education is compulsory as well as free, and that the magnitude of the effect was larger for countries at the lower end of completion rates: average primary graduation rates were estimated to be 9.6 percentage points higher at the 50th percentile and 12.2 percentage points higher at the 25th percentile $(p \leq 0.05)$. Countries with primary school graduation rates in the bottom 25th percentile (among those with data) are low- and low-middle-income countries primarily in sub-Saharan Africa but also including such diverse countries as Bangladesh, Djibouti, and Vanuatu as well (see Table 3).

Table 3 Countries in the first quartile of the distribution of primary school gross graduation rates

\begin{tabular}{|c|c|c|}
\hline Country & Level of income & Region \\
\hline Angola & Lower middle income & Sub-Saharan Africa \\
\hline Bangladesh & Lower middle income & South Asia \\
\hline Benin & Low income & Sub-Saharan Africa \\
\hline Botswana & Upper middle income & Sub-Saharan Africa \\
\hline Burkina Faso & Low income & Sub-Saharan Africa \\
\hline Burundi & Low income & Sub-Saharan Africa \\
\hline Cameroon & Lower middle income & Sub-Saharan Africa \\
\hline Comoros & Low income & Sub-Saharan Africa \\
\hline Republic of the Congo & Lower middle income & Sub-Saharan Africa \\
\hline Djibouti & Lower middle income & Middle East and North Africa \\
\hline Eritrea & Low income & Sub-Saharan Africa \\
\hline Ethiopia & Low income & Sub-Saharan Africa \\
\hline Guinea & Low income & Sub-Saharan Africa \\
\hline Lesotho & Lower middle income & Sub-Saharan Africa \\
\hline Madagascar & Low income & Sub-Saharan Africa \\
\hline Mali & Low income & Sub-Saharan Africa \\
\hline Mauritania & Lower middle income & Sub-Saharan Africa \\
\hline Nigeria & Lower middle income & Sub-Saharan Africa \\
\hline Pakistan & Lower middle income & South Asia \\
\hline Papua New Guinea & Lower middle income & East Asia and Pacific \\
\hline Rwanda & Low income & Sub-Saharan Africa \\
\hline Togo & Low income & Sub-Saharan Africa \\
\hline Tuvalu & Upper middle income & East Asia and Pacific \\
\hline Uganda & Low income & Sub-Saharan Africa \\
\hline Vanuatu & Lower middle income & East Asia and Pacific \\
\hline Yemen & Lower middle income & Middle East and North Africa \\
\hline
\end{tabular}


It is worth highlighting that we find positive benefits of free and compulsory pre-primary when examining a global sample of countries with a wide range of early childhood education contexts including countries with few alternatives in the absence of national pre-primary education and those with many. As reliable data on the availability, quality and use of alternative sources of early childhood education is not currently available on a global basis, it was not possible to account for this in our analysis. However, there is evidence from a handful of developing countries that options are limited, and/or not easily accessible, and that parents may not be aware of or perceive there are benefits of early childhood education (e.g., Rao et al. 2012; Martinez et al. 2012; McCoy et al. 2017).

These results suggest that provision of at least a year of free pre-primary education alone may not be enough to raise primary education graduation rates in countries where graduation from primary school is on the lower end of the spectrum. The addition of a requirement to attend pre-primary school may be necessary to bring about a significant impact on enrollment with potential follow-on consequences for primary school success. Low-income nations are likely to need external supports to build the national preprimary education system that our results suggest are critical to ultimately increasing human capital and national economies.

There are plausible pathways through which compulsory pre-primary education could influence primary school completion. A policy that makes pre-primary education compulsory places responsibilities on both families and government. When attendance is compulsory, families have to find a way to send their children. They must send them even if they are unsure of the benefit and incur residual costs beyond tuition such as transportation or other fees. A compulsory policy also places pressure on the public sector to spend funds to ensure that all age-eligible children can attend preschool, potentially including the development of physical requirements-space, buildings, teaching materials - and the human capital, including teacher education and training. Further research could usefully examine the pathways and causal mechanisms which explain why making at least a year of pre-primary education compulsory in addition to free is more powerful than the provision of free pre-primary alone.

Our findings are also consistent with a growing number of studies conducted in various contexts on both national and sub-national scales showing that preschool attendance is associated with subsequent educational success (Aboud and Hossain 2011; Save the Children 2003; Barnett and Masse 2007; Berlinski et al. 2008, 2009; Cortázar 2015; Jaramillo and Tietjen 2001; OECD 2011; World Bank 2001) with especially strong benefits for children from low-income households (Engle et al. 2011; Deming 2009; Havnes and Mogstad (2011); Dumas and Lefranc (2010); Mingat and Seurat (2011); Martinez et al. (2012). Disparities that children face in early childhood can lay the foundation for lifelong inequalities (Walker et al. 2011). At the same time, research indicates that investments during early childhood years are one of the most effective strategies for alleviating economic inequalities over a lifespan (Heckman 2006; Knudsen et al. 2006). However, progress toward increasing pre-primary provision and enrollment has been slow and uneven. For example, while the global average pre-primary education gross enrollment rate reached $50 \%$ in 2011, it was only $18 \%$ in sub-Saharan Africa (UNESCO 2014).

Is it feasible to extend free and compulsory education for one or more pre-primary years in countries that struggle to meet other social priorities? Numerous countries' 
experiences support an affirmative response. While there are many complex issues of scaling-up small programs (Wolfensohn Center for Development at Brookings 2009), effective pre-primary education programs at scale exist in developing countries from diverse regions, with different governing and economic development approaches. For example, in Vietnam, after the passage of a 1999 law expanding provision of public preschools, enrollment among 3-5-year-olds, particularly in urban areas, increased markedly (Heymann 2006). In 1999, 39\% of children aged 3-5 were enrolled in preprimary schools. Just 8 years later, in 2007, the rate had reached 65\% (UNESCO IS 2017d). In Cuba, the universality of pre-primary education was achieved by 2000 (Tinajero 2010). Kazakhstan made pre-primary education free and compulsory in 1999 (Shaeffer 2015). Two years of free and compulsory pre-primary education have been provided in Ghana since 2007 (RTI International 2011).

Because guaranteeing free pre-primary school can lead to substantial increases in attendance (Diawara 2007), nations expanding provision may face additional costs for new buildings, maintenance, and infrastructure, as well as resources for training additional teachers. While countries currently spending only a small percentage of GDP on education may be able to find funds through re-budgeting and re-prioritizing (increasing their commitment to education), others will likely need to seek external support. Beyond increased funding, social policy intervention programs that are intertwined with schooling have been also shown to increase primary enrollment as they attract demand from the poorest families. For example, a study analyzing surveys of primary school students in 32 African countries targeted by the World Food Programme found that when food is provided at school and is supplemented by extra take-home rations, sustained increases in primary school enrollment can be achieved (an absolute increase of 30\% female enrollment after the first year of the program) (Gelli et al. 2007). A study of Brazil's Bolsa Familia conditional cash transfer program which provides cash benefits to cover education expenses to families who enroll their children in school instead of allowing them to engage in labor found a significant positive effect on primary school graduation rates (Peruffo and Ferreira 2017). The expansion of conditional cash transfer (CCT) program in Ecuador was accompanied by a larger increase in high school enrollment among youth aged 16-18 whose families were beneficiaries compared to youth from non-beneficiary families (Stampini and Tornarolli 2012), following the establishment of a CCT program in the Philippines the proportion of children 6-14 years in school increased markedly, from $78 \%$ in 2009 to $96 \%$ in 2015 (World Bank 2015).

This study's findings should be interpreted with the following limitations in mind. While we used data on pre-primary education policy prior to when primary graduation rate is measured, in particular during the relevant year based on the year of available graduation rate data, we conducted cross-sectional analyses and included the key national-level factors influencing educational attainment. Therefore, our analysis can establish an association but not causation. Studies of outcomes over time in the countries before and after the provision of free pre-primary and a control group are needed to demonstrate causation. Longitudinal data on pre-primary policies for even a single country that would allow for a rigorous analysis of policy change, as well 
as controls for prior and subsequent trends in primary graduation rates are not currently available.

In addition, as this is a country-level study and there are limitations in global data available, we were not able to examine the effects of school-level factors related to the quality of pre-primary education on primary graduation rates. Studies have shown that higher quality pre-primary yields greater gains in school readiness (e.g., Zuilkowski et al. 2012; McCoy et al. 2017) and primary school achievement (Rao et al. 2012 for Bangladesh and Cambodia; Sylva et al. 2011 for England) especially for children from poor households and in poor countries (e.g., Burger 2010; Lazzari and Vandenbroeck 2013; Aboud 2006; Rao 2010; Moore et al. 2008; Sylva et al. 2011; Kagitcibasi et al. 2001). Findings are consistent across a range of measures of quality including the child-teacher ratio, teacher training and tenure, expenditures, etc., but also measures of the psycho-social environment such as interactions between teachers and children and the child-friendliness of the environment, as well as indicators of the use of developmentally appropriate curriculum and pedagogy, etc. (UNESCO 2007; Brukhauf and Hayes 2017; Sylva et al. 2004, 2006; European Commission 2014). Two smaller-scale, programs in the US that targeted children from low-income households, the Perry Preschool Program and the Abecedarian Project are often-cited examples of high-quality early childhood education programs due to their small classes, high teacher-to-child ratio, and well-trained, qualified teachers. Evaluations of these programs found that participants scored better on reading and math achievement tests over a long follow-up period: at ages 8, 12, 15 and 21 years for Abecedarian Project participants (Campbell et al. 2001), and at age 8 (Barnett and Masse 2007) and age 14 in the Perry Preschool Program (Besharov et al. 2011). A study of 65 developed countries participating in the PISA which found better outcomes in countries where pre-primary education was offered for a longer time, with smaller studentto-teacher ratio and greater per-student expenditures. A number of other school-level factors (including comprehensive instruction, e.g., provision of supplemental and remedial education, teacher education, and sufficient instructional materials), and institutional factors such as greater teacher accountability and local governance (Glewwe and Muralidharan 2016; Hanushek and Woessmann 2011, 2017) have been found to affect student achievement and completion and would be valuable for future studies focused on local-level initiatives.

Valuable next steps include gathering quantitatively comparable global data on the quality of pre-primary programs (both public and private), as well as developing the methods of monitoring and research.

There is evidence that quality in pre-primary education can be improved even in resource-constrained environments. For example, India (Government of India 2013), Jamaica Government and Dudley Grant Memorial Trust (2008), and Tajikistan (UNICEF 2013) have all implemented a new curriculum in their Early Childhood Care and Education (ECCE) programs so they are more child-centered and holistic over the past decade. However, to better understand which aspects of pre-primary education are most important and how the relationship to learning outcomes varies by context-critical information for policymakers designing new or modifying existing pre-primary education systems with resource constraints-detailed data on the programs in place in countries across the income spectrum is needed. Analyses of 
the causal impact of pre-primary education on completion of secondary education, as well as on subsequent individual socio-economic achievements, requires longitudinal household and detailed policy data not yet available on a global basis.

As global data on the quality of primary education were not available, it was not possible to rule out with certainty that improvements in the quality of primary school contributed to increased primary completion rates. However, we estimate this is not a highly likely scenario given that recent global assessments show modest, if any, improvements in quality in the areas where quality has been lowest such as in subSaharan Africa (UNESCO 2014).

Lastly, while we systematically analyzed the available comparable sources on laws and policies regarding pre-primary education policy provision, we were not able to incorporate a measure of the level of implementation as there is no global, comparable source of implementation data for current or historical policies. Sources we used did indicate there are nations where implementation has been imperfect and in some instances, very limited. If this is the case then our results may underestimate the impact of fully implemented policies.

\section{Conclusions}

Our analysis of a new global database of pre-primary education policies revealed that the provision of free and compulsory pre-primary education is associated with higher primary gross graduation rates. Average primary graduation rates were nearly 10 percentage points higher at the middle of the graduation rate distribution and 12 percentage points higher in countries with low graduation rates $(p \leq 0.05)$. Importantly, no significant association was found for free pre-primary education alone. Only when it is also compulsory were significant effects found indicating that both are necessary to increase primary education enrollment to the degree required to achieve positive effects on primary completion. These findings provide additional evidence that investments in policies that make pre-primary education universally accessible may yield important educational benefits that in turn would have positive long-term economic consequences.

Abbreviations

CCT: conditional cash transfer; ECCE: Early Childhood Care and Education; EU: European Union; GDP: gross domestic product; OECD: Organisation for Economic Cooperation and Development; SABER: Systems Approach for Better Education Results; UN: United Nations; UNESCO: United Nations Educational, Scientific and Cultural Organisation; US: United States.

\section{Authors' contributions}

All authors have given final approval of the submission. All authors contributed to the choice and implementation of the analytic design, and the interpretation of findings. AE contributed to the design of the study and the database used in the manuscript; drafted and revised the manuscript; oversaw the literature review; and led the acquisition of data, coding, data verification, and analysis. JH conceived the study, developed funding for the initiative, oversaw the design of the database; drafted parts of the manuscript and made critical revisions to the manuscript with respect to important intellectual content. NM contributed to the design of the study, conducted the literature review, drafted portions of the manuscript, and conducted initial acquisition of data, coding, data verification, and analysis. All authors read and approved the final manuscript.

\section{Author details}

${ }^{1}$ WORLD Policy Analysis Center, University of California, Los Angeles, 621 Charles E. Young Dr. South, Los Angeles, CA 90095, USA. ${ }^{2}$ Faculty of World Economy and International Affairs, National Research University Higher School of Economics, Office 313a, 17/1 Malaya Ordynka Street, Moscow 119017, Russia. 


\section{Acknowledgements}

The authors are grateful to Gonzalo Moreno for his assistance with data coding and verification, and Ashley Armstrong, Parama Sigurdsen, and all the members of the WORLD Policy Analysis Center for their support of this work.

\section{Competing interests}

The authors declare that they have no competing interests.

\section{Availability of data and materials}

As of publication date, available for download at our website.

\section{Funding}

The authors are grateful to the Conrad N. Hilton Foundation for its generous support of work on the UN Sustainable Development Goals which contributed to this work.

\section{Publisher's Note}

Springer Nature remains neutral with regard to jurisdictional claims in published maps and institutional affiliations.

Received: 20 February 2018 Accepted: 12 October 2018

Published online: 25 October 2018

\section{References}

Aboud, F. E. (2006). Evaluation of an early childhood pre-school program in rural Bangladesh. Early Childhood Research Quarterly, 21, 46-60. https://doi.org/10.1016/j.ecresq.2006.01.008.

Aboud, F. E., \& Hossain, K. (2011). The impact of preprimary school on primary school achievement in Bangladesh. Early Childhood Research Quarterly, 26(2), 237-246. https://doi.org/10.1016/j.ecresq.2010.07.001.

Barnett, W. S., \& Masse, L. N. (2007). Comparative benefit-cost analysis of the Abecedarian program and its policy implications. Economics of Education Review, 26(1), 113-125. https://doi.org/10.1016/j.econedurev.2005.10.007.

Berlinski, S., Galiani, S., \& Gertler, P. (2009). The effect of pre-primary education on primary school performance. Journal of Public Economics, 93(1-2), 219-234. https://doi.org/10.1016/j.jpubeco.2008.09.002.

Berlinski, S., Galiani, S., \& Manacorda, M. (2008). Giving children a better start: Preschool attendance and school-age profiles. Journal of Public Economics, 92(5), 1416-1440. https://doi.org/10.1016/j.jpubeco.2007.10.007.

Besharov, D., Germanis, P., Higney, C., \& Call, D. (2011). Assessing the evaluations of early childhood education programs (p. 2011). Maryland: Welfare Reform Academy, School of Public Policy, University of Maryland.

Burger, K. (2010). How does early childhood care and education affect cognitive development? An international review of the effects of early interventions for children from different social backgrounds. Early childhood research quarterly, 25(2), 140-165.

Brukhauf, Z. \& Hayes, N. (2017). Quality of childcare and pre-primary education: How do we measure it? Innocenti Research Brief 13. UNICEF Office of Research—Innocenti. https://www.unicef-irc.org/publications/pdf/IRB_2017_13.pdf. Accessed 1 Oct 2018.

Brunello, G., Fort, M., \& Weber, G. (2009). Changes in compulsory schooling, education, and the distribution of wages in Europe. The Economic Journal, 119(536), 516-539. https://doi.org/10.1111/j.1468-0297.2008.02244.x.

Bruns, B. Mingat, A. \& Rakotomalala, R. (2003). Achieving Universal Primary Education by 2015: A Chance for Every Child. The World Bank: Washington, DC. http://siteresources.worldbank.org/EDUCATION/Resources/278200-1089739404514/ achieving_efa_full.pdf.

Camilli, G., Vargas, S., Ryan, S., \& Barnett, W. S. (2010). Meta-analysis of the effects of early education interventions on cognitive and social development. Teachers College Record. https://eric.ed.gov/?id=EJ888457 Accessed 28 Jan 2018

Campbell, F. A., Pungello, E. P., Miller-Johnson, S., Burchinal, M., \& Ramey, C. T. (2001). The development of cognitive and academic abilities: Growth curves from an early childhood educational experiment. Developmental Psychology, 37(2), $231-242$.

Cortázar, A. (2015). Long-term effects of public early childhood education on academic achievement in Chile. Early Childhood Research Quarterly, 32(3), 13-22. https://doi.org/10.1016/j.ecresq.2015.01.003.

d'Aiglepierre, R., \& Wagner, L. (2013). Aid and Universal Primary Education. Economics of Education Review 37 (December). Pergamon: 95-112. https://doi.org/10.1016/J.ECONEDUREV.2013.09.001.

de Guzman Chorny, N., Raub, A., Perry, N., Vaughan Winfrey, E., Looze, J., Savage, K., Waisath, W., Assi, T. M., \& Heymann, S. J. (2014). Facilitating girls' access to quality education: global findings on tuition-free and compulsory education. Policy Brief, WORLD Policy Analysis Center, University of California at Los Angeles. http://worldpolicycenter.org/sites/defau It/files/WORLD_Policy_Brief_Facilitating_Girls\%E2\%80\%99_Access_to_Quality_Education_2015.pdf. Accessed 28 Jan 2018.

Deininger, K. (2003). Does cost of schooling affect enrollment by the poor? Universal primary education in Uganda. Economics of Education Review, 22(3), 291-305. https://doi.org/10.1016/S0272-7757(02)00053-5.

Deming, D. (2009). Early childhood intervention and life-cycle skill development: Evidence from Head Start. American Economic Journal: Applied Economics, 1(3), 111-134. https://doi.org/10.1257/app.1.3.111.

Diawara, R. (2007). Making the case for a year of compulsory pre-primary education for all children. UNESCO International Institute for Capacity Building in Africa Newsletter, 9(2), 5-7.

Dreher, A., Nunnenkamp, P., \&Thiele, R. (2008). Does aid for education educate children? Evidence from panel data. World Bank Development Review, 22(2), 291-314.

Dumas, C., \& Lefranc, A. (2010). Early schooling and later outcomes: Evidence from pre-school extension in France. Thema Working Paper 7. http://thema.u-cergy.fr/IMG/documents/2010-07.pdf. Accessed 28 Jan 2018. 
Duncan, G. J., Dowsett, C. J., Claessens, A., Magnuson, K., Huston, A. C., Klebanov, P., et al. (2007). School readiness and later achievement. Developmental Psychology, 43(6), 1428-1446.

Engle, P. L., Fernald, L. C. H., Alderman, H., Behrman, J., O'Gara, C., Yousafzai, A., et al. (2011). Strategies for reducing inequalities and improving developmental outcomes for young children in low-income and middle-income countries. The Lancet, 378(9799), 1339-1353.

European Commission. (2014). Proposal for Key Principles of a Quality Framework for Early Childhood Education and Care. In Report of the Working Group on Early Childhood Education and Care under the auspices of the European Commission. http://ec.europa.eu/dgs/education_culture/repository/education/policy/strategic-framework/archi ve/documents/ecec-quality-framework_en.pdf.

Gelli, A., Meir, U., \& Espejo, F. (2007). Does provision of food in school increase girls' enrollment? Evidence from schools in sub-Saharan Africa. Food and Nutrition Bulletin, 28(2), 149-155. https://doi.org/10.1177/1564826507 02800203.

Glewwe, P., \& Muralidharan, K. (2016). Improving education outcomes in developing countries: Evidence, knowledge gaps, and policy implications. In E. Hanushek (Ed.), Handbook of the Economics of Education (pp. 653-743). Oxford: Elsevier. https://doi.org/10.1016/B978-0-444-63459-7.00010-5.

Government of India. (2013). National Early Childhood Care and Education (ECCE) Policy, No. 6-3/2009-ECC, September 27, 2013. New Delhi: Ministry of Women and Child Development, Government of India. http://icds-wcd.nic.in/ schemes/ECCE/ecce_01102013_eng.pdf. Accessed 28 Jan 2018.

Grantham-McGregor, S., Bun Cheung, Y., Cueto, S., Glewwe, P., Richer, L., Trupp, B., et al. (2007). Developmental potential in the first 5 years for children in developing countries. The Lancet, 369(9555), 60-70. https://doi.org/10.1016/ s0140-6736(07)60032-4.

Hanushek, E., \& Woessmann, L. (2011). The Economics of International Differences in Educational Achievement. Handbook of the Economics of Education (1st ed., Vol. 3). North Holland: Elsevier.

Hanushek, E. A., \& Woessmann, L. (2017). School resources and student achievement: A review of cross-country economic research. In R. Monica, Y. H. Katsa, \& W. Urika (Eds.), Cognitive Abilities and Educational Outcomes (1st ed., pp. 149-171). Berlin: Springer.

Hao, L., \& Naiman, D. Q. (2007). Quantile Regression. Quantitative Applications in the Social Sciences, 149. Thousand Oaks, CA: Sage Publishing.

Havnes, T., \& Mogstad, M. (2011). No child left behind: Subsidized child care and children's long-run outcomes. American Economic Journal: Economic Policy, 3(2), 97-129. https://doi.org/10.1257/pol.3.2.97.

Heckman, J. J. (2006). Skill formation and the economics of investing in disadvantaged children. Science, 312(5782), 1900-1902. https://doi.org/10.1126/science.1128898.

Heymann, J. (2006). Forgotten Families: Ending the Growing Crisis Confronting Children and working Parents in the Global Economy. New York: Oxford University Press.

Heymann, J. (2013). Children's Chances: How Countries Can Move from Surviving to Thriving. Cambridge, MA: Harvard University Press.

Heymann, S. J., Raub, A., \& Cassola, A. (2014). Constitutional rights to education and their relationship to national policy and school enrollment. International Journal of Educational Development., 39, 121-131.

Holmlund, H., Lindahl, M., \& Plug. E. (2011). The causal effect of parents'schooling on children's schooling: A comparison of estimation methods. Journal of Economic Literature 493(49): 615-51. http://www.jstor.org/stable/23071 724.

Jamaica Government \& Dudley Grant Memorial Trust. (2008). The Jamaica Early Childhood Curriculum for Children Birth to Five Years: a Conceptual Framework. Dudley Grant Memorial Trust/Government of Jamaica: Kingston. http://www.ibe. unesco.org/curricula/jamaica/jm_ecefw_2008_eng.pdf.

Jaramillo, A., \& Tietjen, K. (2001). Early Childhood Development in Africa: Can We Do More for Less? Africa Region Human Development Working Paper Series, World Bank. http://documents.worldbank.org/curated/en/374121468771611 619/Early-childhood-development-in-Africa-Can-we-do-more-for-less-A-look-at-the-impact-and-implications-ofpreschools-in-Cape-Verde-and-Guinea. Accessed 28 Jan 2018.

Kagitcibasi, C., Sunar, D., \& Bekman, S. (2001). Long-term effects of early intervention: Turkish low-income mothers and children. Applied Developmental Psychology, 22, 333-361.

Kattan, R. B. (2006). Implementation of Free Basic Education Policy. World Bank Education Working Paper Series, 7. World Bank: Washington, DC. http://siteresources.worldbank.org/EDUCATION/Resources/EDWP_User_Fees.pdf Accessed 28 Jan 2018.

Knudsen, E. I., Heckman, J. J., Cameron, J. L., \& Shonkoff, J. P. (2006). Economic, neuro-biological and behavioral perspectives on building America's future workforce. Proceedings of the National Academy of Sciences, 103(27), 10155-10162. https://doi.org/10.1073/pnas.0600888103.

Koenker, R. \& Hallock, K. F. (2001). Quantile Regression. Journal of Economic Perspectives, 15(4): 143-156. http://www.econ. uiuc.edu/ roger/research/rq/QRJEP.pdf. Accessed 28 Jan 2018.

Lazzari, A., \& Vandenbroeck, M. (2013). Literature Review of the Participation of Disadvantaged Children and Families in ECEC Services in Europe. In J. Bennett, J. Gordon, \& J. Edelmann (Eds.), ECEC in promoting educational attainment including social development of children from disadvantaged backgrounds and in fostering social inclusion. European Commission: DG EAC.

Magnuson, K., Ruhm, C., \&Waldfogel, J. (2007). Does prekindergarten improve school preparation and performance? Economics of Education Review, 26(1), 33-51.

Martinez, S., Naudeau, S. \& Pereira, V. (2012). The Promise of Preschool in Africa: A Randomized Impact Evaluation of Early Childhood Development in Rural Mozambique. Washington, DC/Westport, CT, World Bank/Save the Children. http:// www.3ieimpact.org/media/filer_public/2013/04/11/3ie_mozambique_ie001.pdf. Accessed 28 Jan 2018.

McCoy, D. C., Zuilkowski, S. S., Yoshikawa, H., \& Fink, G. (2017). Early childhood care and education and school readiness in Zambia. Journal of Research on Educational Effectiveness, 10(3), 482-506.

Michaelowa, K., \& Weber, A. (2007). Aid Effectiveness in the Education Sector: A Dynamic Panel Analysis. In S. Lahiri (Ed.), Theory and Practice of Foreign Aid (pp. 357-385). Amsterdam: Emerald Group Publishing Limited. 
Mingat, A. \& Seurat, A. (2011). Développement des enfants de 0 à 6 ans et pratiques parentales à Madagascar [Development of Children Aged 0 to 6 and Parenting Practices in Madagascar]. Antananarivo, UNICEF, Madagascar. https://halshs.archi ves-ouvertes.fr/halshs-00605037. Accessed 28 Jan 2018.

Moore, A. C., Akhter, S., \& Aboud, F. E. (2008). Evaluating an improved quality preschool program in rural Bangladesh. International Journal of Educational Development, 28, 118-131. https://doi.org/10.1016/j.jijedudev.2007.05.003.

Nielsen, H. D. (2009). Moving toward Free Primary Education: Policy Issues and Implementation Challenges. UNICEF, New York. http://www.unicef.org/socialpolicy/files/Postscript_Formatted_SFAI_SOA_Review_11_December_2009.pdf. Accessed 28 Jan 2018.

OECD. (2011). Does Participation in Pre-Primary Education Translate into Better Learning Outcomes at School? Paris, Organisation for Economic Co-operation and Development. (PISA in Focus, 2011/1 February.) http://www.oecd-ilibrary.org/ education/does-participation-in-pre-primary-education-translate-into-better-learning-outcomes-at-school_5k9h3 62tpvxp-en. Accessed 28 Jan 2018.

Peruffo, M., \& Ferreira, P. C. (2017). The long-term effects of conditional cash transfers on child labor and school enrollment. Economic Inquiry, 55(4), 2008-2030.

Quamruzzaman, A., Mendoza, J. M., Heymann, S. J., Kaufman, J. S., \& Nandi, A. (2014). Are tuition-free primary education policies associated with lower infant and neonatal mortality in low- and middle-income countries? Social Science and Medicine, 120, 153-159.

Rao, N. (2010). Preschool quality and the development of children from economically disadvantaged families in India. Early Education and Development, 21, 167-185. https://doi.org/10.1080/10409281003635770.

Rao, N., Sun, J., Pearson, V., Liu, H., Engle, P. L., Pearson, E., et al. (2012). Is something better than nothing? An evaluation of early childhood programs in Cambodia. Child Development, 83(3), 864-876.

Rao, N., Sun, J., Wong, J., Weekes, B., Ip, P., Shaeffer, S., Young, M., Bray, M., Chen, E., Lee, D. (2014). Early childhood development and cognitive development in developing countries. Department for International Development, Research for Development, Retrieved from https://www.gov.uk/government/uploads/system/uploads/attachment_data/ file/469088/early-childhood-cognitive-dev.pdf.

Richards, J., \& Vining, A. R. (2015). Universal primary education in low-income countries the contributing role of national governance. International Journal of Educational Development, 40, 174-182.

RTI International. (2011). Ghana National Education Assessment: 2011 Findings Report. Accra: USAID. https://learningportal. iiep.unesco.org/en/notice/T1428328319. Accessed 28 Jan 2018.

Ruff, R. R. (2016). The impacts of retention, expenditures, and class size on primary school completion in sub-Saharan Africa: a cross-national analysis. International Journal of Education Policy and Leadership, 11(9), 1-13.

Save the Children. (2003). What's the Difference? An ECD Impact Study from Nepal. Children's Environments Research Group, UNICEF. https://www.unicef.org/evaldatabase/index 29686.html. Accessed 28 Jan 2018.

Shaeffer, S. (2015). The demand for and the provision of early childhood services since 2000: Policies and strategies. Background paper for EFA Global Monitoring Report 2015. http://unesdoc.unesco.org/images/0023/002324/23245 7e.pdf. Accessed 28 Jan 2018.

Shonkoff, J. P., \& Phillips, D. A. (Eds.). (2000). From Neurons to Neighborhoods: The Science of Early Child Development. Washington, DC: Committee on Integrating the Science of Early Childhood Development, National Academy Press.

Stampini, M., \& Tornarolli, L. (2012). The Growth of Conditional Cash Transfers in Latin America and the Caribbean: Did They Go Too Far? IDB Policy Brief No 185. Washington, DC, United States: Inter-American Development Bank. https://publi cations.iadb.org/handle/11319/1448. Accessed 28 Jan 2018.

Sylva, K., Melhuish, E. C., Sammons, P., Siraj-Blatchford, I. \& Taggart, B. (2004). The effective provision of pre-school education (EPPE) Project: Final report. In A Longitudinal Study Funded by the DfES 1997-2004. London: DfES/Institute of Education, University of London.

Sylva, K., Melhuish, E., Sammons, P., Siraj-Blatchford, I., \& Taggart, G. (2011). Pre-school quality and educational outcomes at age 11: Low quality has little benefit. Journal of Early Childhood Research, 9(2), 109-124.

Sylva, K., Siraj-Blatchford, I., Taggart, B., Sammons, P., Melhuish, E., Eliot, K., et al. (2006). Capturing quality in early childhood through environmental rating scales. Early Childhood Research Quarterly., 21, 76-92.

Tinajero, A. (2010). Cuba's Educate Your Child Program: Strategies and lessons from the expansion process, scaling up early child development in the developing world. In Working paper series, 16, April, 2010, Washington, DC: Brookings Institution, Wolfensohn Center for Development at Brookings. https://www.oise.utoronto.ca/guestid/humandevel opment/UserFiles/File/Cuba_Article_2.pdf.

UN Statistics Division. (2013). Millennium Development Goals Indicators: 2.1 Net enrolment ratio in primary education. http:// mdgs.un.org/unsd/mdg/Data.aspx.

UNESCO. (1990). World Declaration on Education for All and Framework for Action to Meet the Basic Learning Needs, World Conference on Education for All, Jomtien, Thailand, 5-8 March 1990. http://unesdoc.unesco.org/image s/0012/001275/127583e.pdf. Accessed 28 Jan 2018.

UNESCO. (2007). Global Monitoring Report Education for All, Strong foundations Early childhood care and education. Available at: http://unesdoc.unesco.org/images/0014/001477/147785e.pdf. Accessed 28 Sept 2018.

UNESCO. (2010). Education for All Goals. http://portal.unesco.org/en/ev.php-URL_ID=22012\&URL_DO=DO_TOPIC\&URL_ SECTION=201.html. Accessed 28 Jan 2018.

UNESCO. (2012). International Standard Classification of Education ISCED 2011. UNESCO Institute for Statistics, Montreal, Canada. http://uis.unesco.org/sites/default/files/documents/international-standard-classification-of-educationisced-2011-en.pdf. Accessed 28 Jan 2018.

UNESCO. (2014). Teaching and learning: Achieving quality for all. UNESCO, Paris, France. http://unesdoc.unesco.org/image s/0022/002266/226662e.pdf. Accessed 28 Jan 2018.

UNESCO. (2015). Education for All 2000-2015: Achievements and challenges. EFA Global Monitoring Report. http://en.unesC o.org/gem-report/report/2015/education-all-2000-2015-achievements-and-challenges\#sthash.pBSt01Rk.dpbs. Accessed 28 Jan 2018.

UNESCO IS. (2017a). UIS.Stat, Education. In Net enrollment rate, primary, both sexes (\%), and gender parity index (GPI), for 2000 and 2015. http://data.uis.unesco.org/Index.aspx. Accessed 28 Jan 2018. 
UNESCO IS. (2017b). UIS.Stat, Education. In Survival rate to the last grade of primary education, both sexes (\%), for 1999 and 2013. http://data.uis.unesco.org/Index.aspx. Accessed 28 Jan 2018.

UNESCO IS. (2017c). UIS.Stat, Education. In Gross graduation ratio from primary education, both sexes (\%) http://data.uis. unesco.org/Index.aspx Accessed 28 Jan 2018.

UNESCO IS. (2017d). UIS.Stat, Education. In Net enrollment rate, pre-primary education, both sexes (\%), Vietnam, for 1999 and 2007. http://data.uis.unesco.org/Index.aspx Accessed 28 Jan 2018.

UNICEF. (2013). UNICEF Supported Early Childhood Education Curriculum Approved by the Ministry of Education of Tajikistan New York, UNICEF. https://www.unicef.org/tajikistan/media_24210.html. Accessed 28 Jan 2018.

UNICEF \& the World Bank. (2009). Abolishing School Fees in Africa: Lessons from Ethiopia, Ghana, Kenya, Malawi, and Mozambique. Washington: The International Bank for Reconstruction and Development/the World Bank. http://www.unice f.org/publications/files/Aboloshing_School_Fees_in_Africa.pdf. Accessed 28 Jan 2018.

Walker, S. P., Wachs, T. D., Grantham-McGregor, S., Black, M. M., Nelson, C. A., Huffman, S. L., et al. (2011). Inequality in early childhood: Risk and protective factors for early child development. The Lancet, 378(9799), 1325-1338. https://doi. org/10.1016/S0140-6736(11)60555-2.

Wolfensohn Center for Development at Brookings. (2009). Scaling up early child development in the developing world: Event summary. Washington, DC: Wolfensohn Center for Development at Brookings. https://www.brookings.edu/wpcontent/uploads/2012/04/20090505_early_child_development_summary.pdf. Accessed 28 Jan 2018.

World Bank. (2001). Brazil Early Child Development: A Focus on the Impact of Preschools. http://siteresources.worldbank.org/ EDUCATION/Resources/278200-1099079877269/547664-1099079922573/Brazil_Early_child_Dev_preschools_En02. pdf. Accessed 28 Jan 2018.

World Bank. (2015). Philippines_PH-Social Welfare and Development Reform: P082144_Implementation Status Results Report: Sequence 09. Washington, D.C.: World Bank Group. http://documents.worldbank.org/curated/ en/2015/12/25711935/philippines-ph-social-welfare-development-reform-p082144-implementation-status-resul ts-report-sequence-09. Accessed 28 Jan 2018.

World Bank. (2017). World Development Indicators. http://data.worldbank.org/data-catalog/world-development-indic ators. Accessed 28 Jan 2018.

Yogo, T. U. (2017). Assessing the effectiveness of foreign aid in the education sector in Africa: the case of primary education. African Development Review, 29(3), 389-402. https://doi.org/10.1111/1467-8268.12276.

Zhang, T., \& Minxia, Z. (2006). Universalizing nine-year compulsory education for poverty reduction in rural China. Review of Education, 52, 261-285. https://doi.org/10.1007/s11159-006-0011-z.

Zuilkowski, S. S., Fink, G., Moucheraud, C., \& Matafwali, B. (2012). Early childhood education, child development and school readiness: Evidence from Zambia. South African Journal of Childhood Education, 2(2), 117-136.

\section{Submit your manuscript to a SpringerOpen ${ }^{\circ}$ journal and benefit from:}

- Convenient online submission

- Rigorous peer review

- Open access: articles freely available online

- High visibility within the field

Retaining the copyright to your article

Submit your next manuscript at $\boldsymbol{~ s p r i n g e r o p e n . c o m ~}$ 